\title{
Pelvic organ prolapse in rural Nepalese women of reproductive age groups: What makes it so common?
}

\author{
Geeta Gurung', Ashma Rana', Archana Amatya', Keshang D. Bista', \\ Ananda B. Joshi,* Jamuna Sayami** \\ 'Dept of Ob/Gyn, Community Medicine* and Nursing Faculty, ** \\ TUTH, IOM, Kathmandu, Nepal.
}

\begin{abstract}
:
Aim: To find out the prevalence, aetiopathogenesis and the magnitude of problems of pelvic organ prolapse (POP) among married women of reproductive age (MWEA) in the rural Nepalese community.

Methods: A cross-sectional descriptive study conducted in eight selected districts (mountain/ hills to terai region) of Nepal linking community to health services. Proportionate samples of MWRA (15-49 years) in total samples of 2849 were interviewed using questionnaires and clinical examinations were made in health facililities.

Results: Among 2849 women who agreed to take part on the study when interviewed (by enumerators with pretested questioners) 2070 (72.6\%) came for assessment. POP was diagnosed in 207/2070 giving the incidence as $10 \%$ being commoner in the planes $(8: 1)$ than mountains. POP formed $2.8 \%$ of adolescent due to early marriage $d^{\prime \prime} 15$ years in (50\%) and unsupported delivery by skilled birth attendant (SBA) out of health facilities (99.2\%).

Resumption of manual labor after delivery less than a month was (83.8\%) and parity was responsible to some extent as $\mathrm{P}_{(1-3)}$ occupied by T!

Mean duration of suffering being 7.8 years ( $e^{\prime \prime} 10$ years in 1/4.) having $1{ }^{\circ} / I^{\circ}$ or procidentia rectovaginal/ vesicovaginal fistula, urinary incontinence (stress/urge), bleeding, discharge from sore and ulceration, coital problem, urination/ defecation problem walking, sitting, back ache and chronic abdominal pain S!.

Conclusion: In this large reproductive morbidity study including women in the rural community of varied ethenic groups from diverse ecology, basic community survey linked to clinical assessment in the health facility found the incidence of POP to be much higher in planes than hills giving unusually lower prevalence rate for POP as $10 \%$ than other clinic based studies.
\end{abstract}

\section{Introduction}

Uterovaginal prolapse is the downward displacement of uterus from its normal anatomical position dragging some parts of vagina, bladder or rectum along with it ascertained by the appearance of cervix below or in and around vaginal introitus. This has been fairly believed to occur from the loss of uterine support resulting from unattended multiple child birth accentuated by heavy manual work in the immediate puerperium in the majority of rural Nepalese women. ${ }^{1-3}$ As a matter fact globally many studies have been looking into the aetipathogenesis of prolapse such that a recurrence after the primary surgery can be is minimized. We in reality are occupied to know "how" big in the problem "what" can we do? Lot of attention being focused aiming to overcome morbidity prevailing in the communities nationwide. ${ }^{3-6}$

\section{Methods}

This reproductive health morbidity study was conducted between November 2005 - May 2006 by IOM (under financial support of UNFPA/WHO) was a cross

Correspondence

Dr. Geeta Gurung, DGO, FCPS

Assoc Prof. Dept Obs/Gyn, TUTH

Email: gurunggeeta@hotmail.com 
Table I. Eduard Jongstra sampling method

\begin{tabular}{|c|c|}
\hline & $\begin{array}{c}N=z^{2} \times(r) \times(1-r) \times(f) \times(1+q) \quad X D^{0.65} \\
\left.\left[e^{2}\right) \times(p) \times\left(n_{h}\right)\right]\end{array}$ \\
\hline $\mathrm{N}=$ & required number of household (married women aged 15-49 years) \\
\hline $\mathrm{z}=$ & a factor to achieve certain level of confidence. $Z$ has a value of 1.96 for $95 \%$ confidence interval \\
\hline $\mathrm{r}=$ & $\begin{array}{l}\text { prevalence or incidence of the key indicator for the smallest population subgroup that the survey } \\
\text { targets. It is set at } 0.33 \text { (prevalence of reproductive morbidity) }\end{array}$ \\
\hline $\mathrm{f}=$ & a factor to account for the design effect. For moderate clustering its value is 1.75 . \\
\hline $\mathrm{q}=$ & $\begin{array}{l}\text { the proportion of non response that is allowed or anticipated. The value of } 0.10 \text {, which represents } 10 \\
\text { percent non response, is considered reasonable }\end{array}$ \\
\hline $\mathrm{e}=$ & $\begin{array}{l}\text { is the margin of error of the key indicator. For indicators with moderate to high coverage a value of } 0.05 \\
\text { is recommended. P is the proportion of the total population that the smallest sub-population subgroup } \\
\text { comprises. The married women aged } 15-49 \text { year age comprise on the average } 20 \% \text { of the total population } \\
\text { in Nepal (estimation made from DHS Annual Report, 2003, 2004) }\end{array}$ \\
\hline$\left(\mathrm{n}_{\mathrm{h}}\right)=$ & $\begin{array}{l}\text { is the average size of households. In Nepal this is } 5.1 \text { people according to } 2001 \text { census D is the } \\
\text { (maximum) number of domain of analysis i.e the number of sub region/sub groups for which indicators } \\
\text { are to be calculated. Hence, D takes on a value of } 3 \text {. }\end{array}$ \\
\hline
\end{tabular}

sectional descriptive study consisting of 2 basic components as research design. The first part involving field survey in six PARHI districts (Mahottari, Rautahat, Kapilbastu, Dang and Dadeldhura Saptari) of UNFPA with 2 more additional districts Jumla and Baglung where all the women falling within the predetermined sample size were interviewed from each household. Clusters in the beginning were requested to come for clinical assessment in the hospital or health post of the respective district aimed at linking community to the district level health services. Study population included reproductive age groups of 15-49 years from 98 such clusters each consisting of 30 household that fulfilled the total estimate of 2940 subjects as derived from Eduard Jongstra sampling method (Table1).

Process involved were construction of questionnaires which were pre-tested in 100 MWRA in rural VDCs of Kathmandu. Supervisors along with enumerators prepared an operational action plan for field survey such that the interview could be smoothly conducted as designed with only one married women of reproductive age per household who agreed to come for follow up in district level hospital for further clinical assessment, gynecological examination. These women were also subjected for laboratory investigation such as hemoglobin estimation, serum RPR, HbsAg along with high vaginal swab for bacterial vaginosis, Trichomonas and candidiasis (wet mount) incorporating immunochromatographic assay of endo cervical swab for chlamydia or cervical discharge for gonorrhea. Ethical approval was obtained from Ethical Review Committee, Institute of Medicine. Data Management and Analysis were entered using EPI Version 6 and processed using Epi Info Version 6 and
SPSS version 10. Data analyzed were either from interviewed population (2849) making a clinical correlation with the examined women $(n=2070)$ who were detected to have POP $(\mathrm{n}=207)$ whichever were found to be applicable.

\section{Result}

Although sample size of 2940 was mapped out in the beginning, 2849 women from the respective districts falling proportionately to the number of total women population who participated in the study during the field survey were interviewed by enumerators. Of them only 2070 (72.6\%) who came for clinical examination represented from 8 districts were as follows: Saptari 396(535), Kapilbastu 351(449), Rautahat 332(491), Dang 359 (430), Mahottari 323(509), Baglung 178(228), Dadeldhura 57 (117) and Jumla 74(90). In total 216 complained of pelvic organ (POP) and was clinically demonstrable in $95.8 \%$ thus giving prevalence of POP to be $10 \%(207 / 2070)$.

Prevalence of POP was significantly higher in Tarai region 8.84 (1402) comprised by Saptari, Mahottari, Kapilbastu and Rautahat than Hilly region such as Baglung, Dadeldhura, Jumla and Dang affecting and $1.16(668)$ of women respectively. Rautahat was district having a prevalence of $44.5 \%$ in 332 total women examined. Next keen in descending order were Saptari 27.6\% (396), Dadeldhura 17.7\% (57), Kapilvastu 11.1\% (351), Mahottari 7.4\% (323) Jumla 4.2\% (74), Baglung $3.5 \%$ (178) and Dang 2.8\% (359) respectively. After Saptari, it was Dang where the maximum numbers of women were examined clinically, however, prolapse was found to be one of the lowest. 
Table 2. Pelvic organ prolapse in eight districts

\begin{tabular}{|c|c|c|c|c|c|c|c|c|c|}
\hline Factors & Rautahat & Dang & Dadeldhura & Mahottari & Saptari & Kapilvastu & Baglung & Jumla & Total \\
\hline \multicolumn{10}{|l|}{$\begin{array}{l}\text { Caste/Ethnicity } \\
(\mathrm{n}=2849)\end{array}$} \\
\hline Socially Excluded ${ }^{\$}$ & $\begin{array}{c}14 \\
(2.9)\end{array}$ & $\begin{array}{c}60 \\
(14.0)\end{array}$ & $\begin{array}{c}15 \\
(12.8)\end{array}$ & $\begin{array}{c}11 \\
(2.2)\end{array}$ & $\begin{array}{c}8 \\
(1.5)\end{array}$ & $\begin{array}{l}19 \\
(4.2)\end{array}$ & $\begin{array}{c}41 \\
(18.0)\end{array}$ & $\begin{array}{c}12 \\
(13.3)\end{array}$ & $\begin{array}{l}180 \\
(6.3)\end{array}$ \\
\hline $\begin{array}{l}\text { Socially Excluded } \\
\text { (Terai)** }\end{array}$ & $\begin{array}{c}133 \\
(27.1)\end{array}$ & $\begin{array}{c}2 \\
(0.5)\end{array}$ & $\begin{array}{c}4 \\
(3.4)\end{array}$ & $\begin{array}{c}46 \\
(9.0)\end{array}$ & $\begin{array}{c}84 \\
(15.7)\end{array}$ & $\begin{array}{c}34 \\
(7.6)\end{array}$ & $\begin{array}{c}1 \\
(0.4)\end{array}$ & $\begin{array}{c}0 \\
(0)\end{array}$ & $\begin{array}{l}304 \\
(10.7)\end{array}$ \\
\hline \multicolumn{10}{|l|}{ Age at marriage (2849) } \\
\hline Low thru $15 \mathrm{yrs}$ & $\begin{array}{l}329 \\
(67.3)\end{array}$ & $\begin{array}{c}148 \\
(34.5)\end{array}$ & $\begin{array}{c}51 \\
(43.6)\end{array}$ & $\begin{array}{l}389 \\
(76.4)\end{array}$ & $\begin{array}{c}242 \\
(45.2)\end{array}$ & $\begin{array}{c}257 \\
(57.2)\end{array}$ & $\begin{array}{c}50 \\
(21.9)\end{array}$ & $\begin{array}{c}39 \\
(43.8)\end{array}$ & $\begin{array}{c}1505 \\
(52.9)\end{array}$ \\
\hline 16- 19 yrs & $\begin{array}{c}131 \\
(26.8)\end{array}$ & $\begin{array}{c}223 \\
(52.0)\end{array}$ & $\begin{array}{c}54 \\
(46.2)\end{array}$ & $\begin{array}{l}109 \\
(21.4)\end{array}$ & $\begin{array}{c}267 \\
(49.9)\end{array}$ & $\begin{array}{c}150 \\
(33.4)\end{array}$ & $\begin{array}{l}141 \\
(61.8)\end{array}$ & $\begin{array}{c}36 \\
(40.4)\end{array}$ & $\begin{array}{l}1111 \\
(39.1)\end{array}$ \\
\hline $\begin{array}{l}\text { Age at first child birth } \\
<=19 \text { yrs }\end{array}$ & $\begin{array}{c}380 \\
(77.4)\end{array}$ & $\begin{array}{c}291 \\
(67.7)\end{array}$ & $\begin{array}{l}74) \\
(63.2\end{array}$ & $\begin{array}{c}420 \\
(82.5)\end{array}$ & $\begin{array}{c}428 \\
(80.0)\end{array}$ & $\begin{array}{c}338 \\
(75.3)\end{array}$ & $\begin{array}{c}104 \\
(45.6)\end{array}$ & $\begin{array}{c}60 \\
(66.7)\end{array}$ & $\begin{array}{l}2095 \\
(73.5)\end{array}$ \\
\hline \multicolumn{10}{|l|}{$\begin{array}{l}\text { Assistance at del } \\
(\mathrm{n}=2586)\end{array}$} \\
\hline Mother/Sasu/Neighbor & $\begin{array}{c}373 \\
(85.7)\end{array}$ & $\begin{array}{c}301 \\
(72.7)\end{array}$ & $\begin{array}{c}45 \\
(40.2)\end{array}$ & $\begin{array}{c}396 \\
(86.1)\end{array}$ & $\begin{array}{c}425 \\
(86.7)\end{array}$ & $\begin{array}{c}309 \\
(81.3)\end{array}$ & $\begin{array}{c}151 \\
(70.9)\end{array}$ & $\begin{array}{c}43 \\
(52.4)\end{array}$ & $\begin{array}{l}2043 \\
(79.0)\end{array}$ \\
\hline None & $\begin{array}{c}9 \\
(2.1)\end{array}$ & $\begin{array}{l}15 \\
(3.6)\end{array}$ & $\begin{array}{c}38 \\
(33.9)\end{array}$ & $\begin{array}{c}20 \\
(4.3)\end{array}$ & $\begin{array}{c}13 \\
(2.7)\end{array}$ & $\begin{array}{c}13 \\
(3.4)\end{array}$ & $\begin{array}{c}7 \\
(3.3)\end{array}$ & $\begin{array}{c}8 \\
(9.8)\end{array}$ & $\begin{array}{l}123 \\
(4.8)\end{array}$ \\
\hline \multicolumn{10}{|l|}{ Post delivery rest } \\
\hline 31 days and more & $\begin{array}{l}40 \\
(9.2)\end{array}$ & $\begin{array}{c}71 \\
(17.1)\end{array}$ & $\begin{array}{c}10 \\
(8.9)\end{array}$ & $\begin{array}{c}48 \\
(10.4)\end{array}$ & $\begin{array}{c}25 \\
(5.1)\end{array}$ & $\begin{array}{c}64 \\
(16.8)\end{array}$ & $\begin{array}{c}32 \\
(15.0)\end{array}$ & $\begin{array}{c}10 \\
(13.2)\end{array}$ & $\begin{array}{l}300 \\
(11.6)\end{array}$ \\
\hline $\begin{array}{l}\text { Not using FP Devices } \\
\mathrm{N}=2848\end{array}$ & $\begin{array}{l}350 \\
(71.3)\end{array}$ & $\begin{array}{c}206 \\
(48.0)\end{array}$ & $\begin{array}{c}88 \\
(75.2)\end{array}$ & $\begin{array}{l}343 \\
(67.4)\end{array}$ & $\begin{array}{c}390 \\
(72.9)\end{array}$ & $\begin{array}{c}369 \\
(82.2)\end{array}$ & $\begin{array}{c}119 \\
(52.2)\end{array}$ & $\begin{array}{c}61 \\
(67.8)\end{array}$ & $\begin{array}{l}1926 \\
(67.6)\end{array}$ \\
\hline
\end{tabular}

Age and POP: Of the total 2849 women interviewed majority (38.5\%) were in the age group 20-29 years and least numbers were formed by the age group 19 years and below $(5.7 \%)$. However considerable proportions of women were of the age group 30-39 years (34.2\%) and $40-49$ years $(21.7 \%)$. The similar age distribution pattern was also observed in all districts but percentage representation of POP was mainly calculated for clinically examined cases in specific age groups.

In the examined population $(\mathrm{n}=2070)$ POP was seen in different age groups starting at 15-19 (2.8\%), 20$24(3.5 \%), 25-29(7.1 \%), 30-39(21.9 \%)$ [30-34(8.3\%), 35$39(13.6 \%)]$ and $40-49(24.1)]$.

Parity and POP: In general population prolapse was present right after the very first childbirth and was present in 5.1, 9.2 10.1 and $18 \%$ in P1, P2, P3-4 and $>$ P4 respectively as compared to $6.9,19.3,40.1$ and $33.7 \%$ within the groups POP diagnosed (Fig 2).

Contributing factors for POP were because of marriage at a very young age d" 15 years (50.2) Mahottari (76.4\%), followed by Rautahat (67.3\%), Kapilvastu
$(57.2 \%)$ which in some places were even before $14-15$ years (Table 2). Conversely marriage between the age 16 -19 took place maximum in Baglung (61.8\%), Saptari (49.9\%) and $46.2 \%$.

Early marriage /childbirth and POP well co-related, early being the root cause adversely influenced the early child birth in the total interviewed population (2849) living in different districts within various cultural background. Sequentially represented in accordance to highest percentage of child birth at age d" nineteen (Table2) was Mahottari 82.5\% (420/509); Saptari 80\% (428/535), Kapilvastu 75.3\% (338/449), Rautahat 77.4 $\%$ (380/491), Dang 67.7\%(291/430) areas were POP was generally found to be higher with respect to others like Dadeldhura 63.2\% (74/117), Jumla 66\% (60/90) and Baglung 45.6\% (104/228). This cooperated in increasing frequency of POP in general population thus representing maximum value for grandmultipara (who gave e"4 viable births) which is slightly different from POP in the small group of affected population $(n=207)$ having incidence after $3-4^{\text {th }}$ child birth to be the highest (Fig $2 \& 3$ ). 


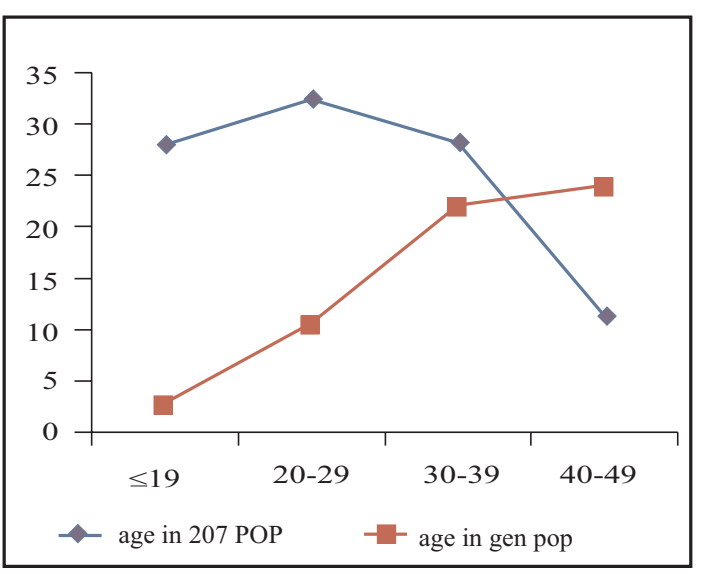

Figure I. POP within and general population

Illiteracy $32.4 \%$ [(highest Saptari $(87.3 \%)$ and lowest Baglung (28.5\%)] running parallel to non contraceptive seeking behavior in $67 \%$ current contraception non acceptors were an additional factor which were enough for leaving poor impact on vaginal floor with each recurrent birth thus attributing to POP. Amongst other determining factors were self assisted (4.8\%) or delivery conducted by untrained personnel (mother, mother-inlaw and neighbor) $79 \%$ delivery occurring at home $(91.3 \%)$, cow shed $(0.7 \%)$ or farm $(0.2 \%)$ during their last child birth. Most women $(\mathrm{n}=2580)$ confined to less of puerperal rest, returning to work within the next 7 days 307 (11.9\%) 8-14 days 652 (25.3\%) 15-30 days $1321(51.2 \%)$ and after a month $300(11.6 \%)$ in $n$ their respective occupation like agriculture 1037 (42.5\%); daily wage earner 499 (20.5\%), own business 286 (11.7\%) official Governmental job $206(8.4 \%)$ and organizationational works in others $60(2.5)$

\section{Part II within the pop $(\mathbf{N}=207)$}

POP and age distribution: amongst women having prolapse ( $\mathrm{n}=207)$ was $28.2 \%$ in adolescent, $32.4 \%$ in age group $20-29,28.2 \% 30-39$ and $11.3 \%$ in age group of 40-49 The mean age at first occurrence of POP was 27.9 years. Prolapse in the young age resulted as a consequences of early marriage, conception and delivery at a younger age having been influenced by recurrent child birth. Each parity increasing tendency to POP as a consequence to perineal trauma. As shown by parity: P1 (6.9\%), P2 (9.3\%), P3-4 (40.1\%) and >P4 (33.7\%) among 202.

POP and symptoms related to descents or herniation of the pelvic organ (uterus, rectum or bladder into the vagina in majority of women at the time of presentation mainly were from highest order of frequency being abdominal pain (96.9\%), long standing back ache (72\%), difficulty in standing, sitting and walking (33.8/32.9\%/ $30.4 \%$ ) difficulty in lifting (32.9\%) vaginal foul smelling discharge/itching $(33.3 \%) /(18.1 \%)$; Sore or ulcer in

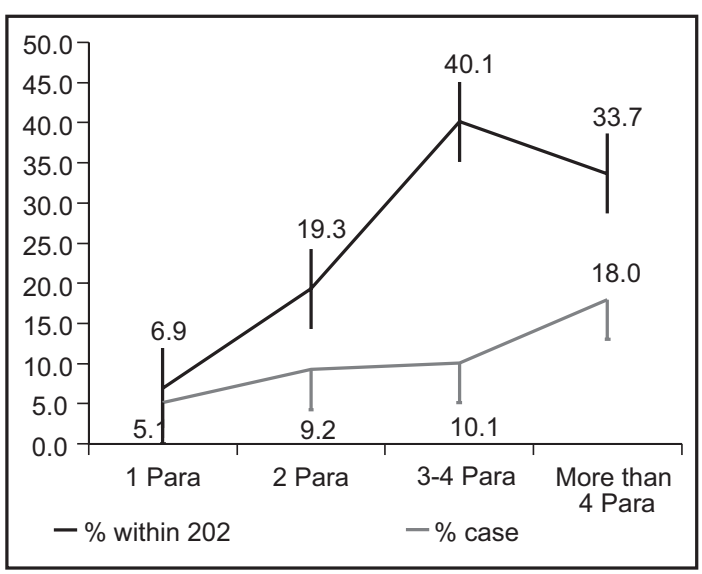

Figure 2. Parity and POP in general population.

protrusion of tissue $(18.8 \%)$, painful coitus/intercourse (15.0\%); and menorrhagia (6.4\%). Complaints related to urinary symptoms were present in $71.4 \%$ which ranged from urinary frequency and burning micturition $33 \%$, difficulty in urinating or incomplete voiding $(25 \%)$, urinary incontinences [urge $(6.9 \%)$ and stress (3.9\%)] and vesicovaginal fistula in 2 cases. Symptoms related to bowel were difficulty in passing stool $(9.8 \%)$ and a case of rectovaginal fistula.

POP and sufferings in years were $<11$ years or up to 10 yrs $73.9 \%$ [ $<5$ yrs $(47.10 \%)$; 5-10yrs $(34.8 \%)]$; $11-20$ years in $20.8 \%$ [ $11-15 \mathrm{yrs}(11.30 \%)$ and $16-20 \mathrm{yrs}(4.4 \%)$ ] and invariably for $21-30$ years in $4.3 \%$. Mean duration suffering from POP remaining as 7.89 years and was not remembered by $1 \%$.

Different degrees represented are I degree (37.2\%) $\mathrm{II}^{\circ}$ (12.6) and $\mathrm{III}^{\circ}(16.82 \%)$ and procedentia $1.4 \%$ and at least $40.8 \%$ would immediately benefit from surgery were cases of major degrees of prolapse $\left(\mathrm{II}^{\circ} / \mathrm{III}^{\circ} /\right.$ procidentia) mainly including second and third degrees of uterovaginal prolapse as well as procedentia. Latter is being addressed to a condition of severe degrees of uterovaginal prolapse where even the uterine fundus remains outside amenable to digital palpation.

\section{Discussion}

Prevalence of pop was found to be $10 \%$ in this community based study having a true representation of women from all parts of rural Nepal, Tarai as well as hilly regions thus identifying problems from severity of prolapse. A clinic based study done in far western Nepal (FHD, GTZ AND UNFPA 2000) has shown higher prevalence of POP as high as $25.1 \%$ when the subjects studied were women not from general population. ${ }^{1}$ Similar paper updated the findings of two studies, one ethnographic and one clinic-based in western Nepal. The ethnographic study involved 16 focus group discussions with 120 community members and key informants and covered community perceptions and 


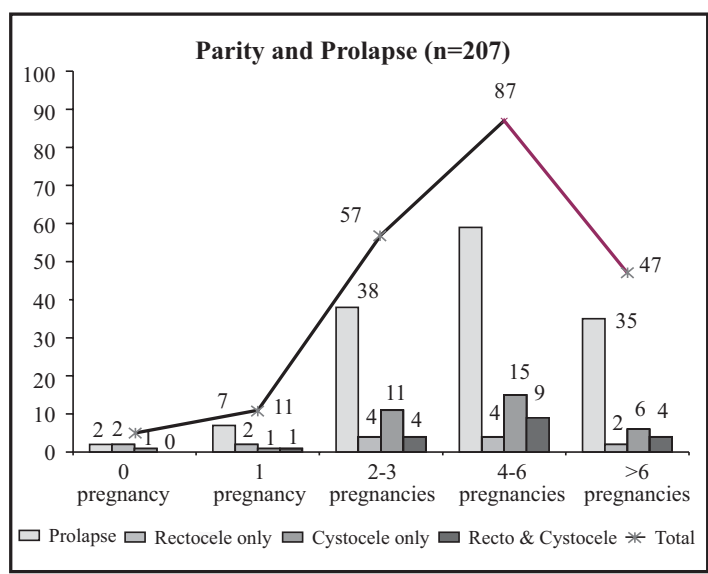

Figure 3. Prolapse and parity within prolapse.

women's experience of prolapse and its perceived causes and consequences. The clinic-based study like in our study was conducted among 2,072 women who presented with gynaecological complaints and received a diagnosis. One in four of them had POP of which $95 \%$ had self-reported the prolapse. Our number from clinical coverage of 2, 070; only $216(10.435 \%)$ who complained of POP with detection in $207 .^{2}$ Meaning that only 1 in 10 women did have the problems from prolapse which must be because of the true representation of the population with wide areas of coverage from hills, Mountainous and Tarai region from different part of the country and not only a segregated part. Other reason being inclusion of balanced population of MWRA in the community as per sampling technique selected from each house hold, categorized as to who could be a normal or diseased women. Most study have involved women from all the age groups and not restricted to age 15-49 years in our study. One of the study in an isolated areas over a certain geographical rural populations of Siraha, Gorkha, Nuwakot have given swinging incidence of prolapse from 16 -35\% during gynaecological morbidity camp survey. ${ }^{3}$ Even the adolescent being the sufferer in $22.2 \%-23.5 \%$ in Achham and Doti such that the mean age of the onset was 27 ; women in age group of 20 - 29 years suffering from $43.8 \%-44.6 \%$ in both districts total 10 years as a mean duration suffering from POP. ${ }^{1}$

With the beginning of the millennium morbidity from POP became a huge concern in Nepal due to the high prevalence, projected as high as $35 \%$ in community setting with drastic variation of around $9.6 \%$ (10\% of the 1147) in urban hospitals of the capital reflecting a greater extent of reproductive morbidity (Ranabhat R. "Study in risk factors belief, and care practices of women with utero-vaginal prolapse". Unpublished dissertation: TUTH, 1996). Beyond this a 4 years study done in Bhaktapur district has shown a very low incidence of genital prolapse, as low as $0.8 \%(135 /$ $16,407)$ with higher prevalence in farmer women $(97$ : 38) to non farmers. Several reasons for hospital attendance besides POP have diluted the prevalence. ${ }^{4}$ The striking discrepancies in the incidences of pelvic organ prolapse have been mainly from where and how the data is taken and interpreted with regards to women suffering only from POP against deceased (other morbidities) or general population of the gynecological morbidity camps..$^{1-3}$ If POP is present in 97 out of entire women of Bajhang attending one of Gynaecological camp therefore would have 2 expressions either total women population which comes around 18\% (97/530) or against filtered women having some gynaecological problems 35\% (97/273); overall 51.5\% (273/530) having one or other problems related to gynecology. ${ }^{5}$ This explains how the incidence/prevalence of POP is retrieved.

Prolapse has constituted about $60 \%$ of the major surgery (Satyal I. Vaginal Prolapse. NARI : 20032 (15)), Kathmandu, Kantipur (local daily) publications made in Nepali] in one of busiest hospital of the Kathmandu valley. Thus comprising $12-17 \%$ of all the gynecological surgery in our own hospital. ${ }^{6-8}$ Figures from the same hospital in the recent years have shown uterovaginal prolapse $(37.1 \%)$ was the commonest indication of overall hysterectomy $(n=221)$ and accounted for $98.8 \%$ of vaginal hysterectomies. ${ }^{9}$ Apart from this vaginal hysterectomy has formed S! of total hysterectomy where 19/50 (38\%) were vaginally operated amongst 20 cases of II U-V prolapse $1(2 \%)$ with previous caesarean undergoing an abdominal hysterectomy in other University Teaching Hospital, vaginal hysterectomy producing lesser post operative complications. ${ }^{10,11}$

POP IN LANDS AND HILLS: A higher incidence of severe degree of uterovaginal prolapse put together from various small survey of districts have raised an important public health issues giving higher prevalence in hilly areas as compared to plain/urban districts. This study findings giving a contrasting findings with observations of high percentage of POP in Rautahat (44.5\%) and Saptari (27.6\%) districts in comparison to hilly districts of Jumla $(n=72)$ and Baglung $(n=178)$ bringing a new insight to our former belief. In the mean time the prevalence of POP was found to be high in Dadeldhura (17.7\%) in comparison to none in Jumla, possible reason may be the inaccessibility of the health care system in this remote hilly region. The other explanation is that the proportion of deliveries attended by sudenis or TBA were highest in Jumla and dang (6 out of 10) giving a fair explanation for the lesser number of POP. It's really surprising that $162(6.3 \%$ of 2586$)$ of delivery cases were also handled by doctors in the total population.

POP AND PARITY in the current study had almost one in every third women $(30.4 \%)$ who noted prolapse after the first child birth which is an important issues meaning the subsequent pregnancies to have been affected by prolapse thus indicating a mean years of sufferings to 
be 7.89. The speculations made so far (in death of researches) have been unattended deliveries $(4.8 \%)$ or if at all they were it had to be mother and mother in laws $(79 \%)$ and $>90 \%$ deliveries taking place at home where women are incorrectly forced to bear down forcefully when a part of uterus and most part of the vaginal walls are extruded out of the introitus in extreme situations post partum, a bitter experiences faced by young women after a single childbirth in approximately $40 \% .^{1}$ Partially governed by poor nutrition and inadequate puerperal rest commencing their routine works as early as one week in $11 \%$ putting a strain in the soft pelvic tissue, work description routine meaning any kind of household activity which they have been already accustomed to, beginning manual labor consisting of carrying heavy loads in true sense; observed everyday in $38.2 \%$ women. And such loads were carried in the basket or on their back (Doko) by $15.9 \%$ or on their head in $15.7 \%$ or over the waist (11.1\%). Carrying of such heavy loads were up to seven times per week in 93.2\%. Tight patuka (yards of clothes) worn by $38.1 \%$ women during post partum period to enable them to carry heavy loads in fact contributed in increasing abdominal pressure in addition.

In consonance with the early marriage practice prevalent throughout rural Nepal age at first pregnancy and first birth was reported highest (73.5\%) in the age group d"19 years with most birth taking place out of health facility [At the national level, only 7.8 percent of births delivered in health facilities] is not surprising. With poor acquisition of family planning methods in the background of poor literacy and predisposition to successive multiple births in rapid succession augmented by marriage/first delivery in youth precluding proper postnatal rehabilitation corroborating to the aetiology of POP. Most important etiology generally related to POP is the early resumption of household works along with the start of puerperal manual labor, which this study too has identified.

MAIN PART OF POP dealing with the mean years of sufferings was found to be 7.89 years, although the years of suffering were for many years, 21-30 years in $4.3 \%$. Symptoms in majority of these women with POP at presentation primarily from natural call like urination $71.4 \%$ [burning micturation (33\%) in difficulty in passing urine $(25 \%)$, stress incontinence $(3.9 \%)$, Urge $(6.9 \%)$ and true incontinence (vesicovaginal fistula) in 2 cases ] or defecation $(9.7 \% \%)$ and stool incontinence rectovaginal fistula ( 1 case ) are annoying, never the less vaginal itching $(18.1 \%) /$ foul smelling vaginal discharge $(33.8 \%)$ and bleeding from ulceration of prolapse mass $(5.4 \%)$ ] equally bothersome. While this study came across abdominal pain $(96.9 \%)$ which is a unique finding. All these symptoms thus are indicating poor quality of life budging from back ache for prolonged period experiencing difficulty even during daily activities like walking, standing and sitting leaving aside difficulty in passing urine and stool less to talk about intercourse. Discharge per vaginum and ulcer on the prolapse (fig 4) were the other morbid factors suggesting poor quality of life stretched over the years whose sufferings from POP was up to 20-30 years with mean duration recorded as 7.89 years.

POP is assumed to be induced by child birth in much younger population ( $14 \%$ before the age of $20,44 \%$ at the age of 20-29 and rest $45.1 \%$ after the age of 30) and majority of the women having had their last child birth at home, cowshed and farm without having proper assistance during birth. Accentuation of POP was attributed by wearing of tight patuka in $38.1 \%$ during postpartum period thereby increasing abdominal pressure serving as a compounding factor. Along with resumption of works not just limited just to household works which constituted of routine manual labor like carrying heavy loads in $38.2 \%$ who were carrying fire woods or water in their back (Doko) $15.9 \%$ or on their head in $15.7 \%$ or over the waist $(11.1 \%)$. Carrying of such heavy loads was taken up to seven times per week in $93.2 \%$. As occupation were simply limited to selling of farm /agriculture products were $53.4 \%$ and daily wage earner 27.5 . Up to $(60.0 \%)$ respondents' from Saptari and lesser number of women were indulged in civil services.

Unlike in the developed world where POP is commonly seen in the postmenopausal age group that could be possibly related to child birth, POP was found in younger population ( $14 \%$ before the age of $20,44 \%$ at the age of $20-29$ and rest $45.1 \%$ after the age of 30 ) where mean age of prolapse was found to be 27.91 years which significantly shows long years of suffering beginning relatively from a younger age. This finding coincides with other research in Nepalese population (Bonetti 2000; Ranabhat 1997; Watson 1975). The most intriguing part of our study being preponderance prolapse in plane and not in hills, similarly noted also in other mountainous region keeps us confirmed about the correctness of our findings. (Pant PR "None with uterovaginal prolapse in Manang gyneacological camp.

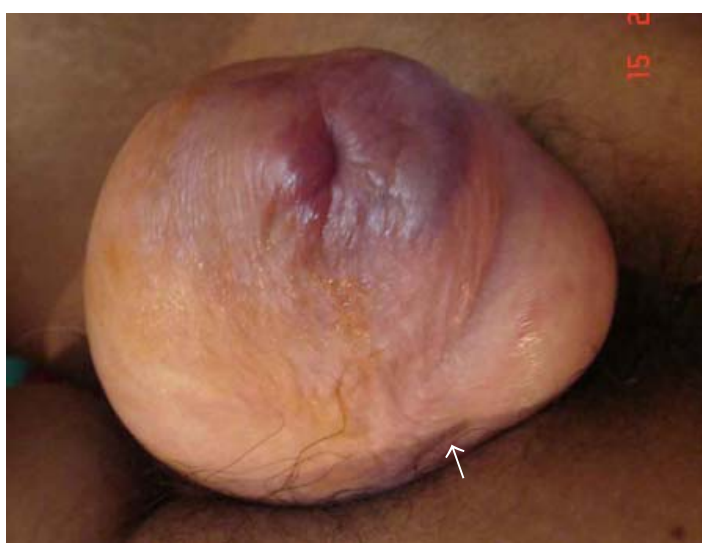

Figure 4. A pencil line ulcer in the side of the procidentia that could go unrecognized. 
Gynaecology and Obstetric Annual health letter 2003; Vol 9: 59-60)

POP included different degrees of POP [first degree $\left(\mathrm{I}^{\circ}\right)$; second degree with or without cystocele / rectocele. That is, majority of the women with POP were diagnosed concomitantly to have cystocele, rectocele or both; where as some women presented only with cystocele/ rectocele or both together without uterovaginal prolapse. Pelvic exercises may at one time be sufficient for minor degrees (first) of POP. Major degrees (second and third degrees, procedentia) in association of rectal prolapse, genitourinary fistula, with some unusual cases needing corrective surgery were found in majority of the women $30.9 \%$ demanding of definite surgery (Fig 4). ${ }^{12-14}$

\section{Conclussion}

In this large reproductive morbidity study encompassing women in the rural community of varied ethenic groups from diverse ecology undergoing a basic health survey linked to health facility; clinical assessment evaluated the incidence of POP to be much higher in planes than hills giving unusually lower prevalence rate for POP as $10 \%$ : severe degrees of prolapse suffered from adolescence besides being associated with rectovaginal vesicovaginal fistula; demanding surgery in almost $40 \%$, thus implying a reproductive morbidity.

\section{Acknowledgements}

We would like to thank UNFPA/WHO for funding this research projects. We would also like to acknowledge the hard efforts put by the entire team members for carrying out the research work and Mr Vijay Malla especially who helped us in the analysis of the datas.

\section{References}

1. Bonetti $T$ R. Erpelding A, Pathak LR. "Reproductive Morbidity- a neglected issue? A report of a clinic based study held in Far-Western Nepal" Kathmandu, Nepal: Ministry of Health, GTZ and UNFPA.2002; chapter 4: 26-30.

2. Bonetti TR, Erpelding A, Pathak LR. Listening to the "felt needs": investigating genital prolapse in western Nepal. Reprod Health Matters. 2004 May; 12(23):166-75.

3. Pant. A. Managing genital prolapses in women of rural Nepal (2005). http://www.anmf.net/ projects $/ 2005$ projects $/ 04 \mathrm{kmh} 001 . \mathrm{htm}$.
4. Vaidya A. Genital prolapse:Disability of women farmers in Bhaktapur. JIOM 2004; 26(3): 15-18

5. Tuladhar H. An overview of reproductive health of women in Bajhang districts. Nepal Med Coll J. 2005 Dec; 7(2):107-11.

6. Rana A, Singh M, Gurung G, Pradhan N. Uterovaginal prolapse as a gynaecological morbidity in T.U.Teaching Hospital. International Journal of Gynaecology and Obstetrics. 2000; 70(2):B68.

7. Gurung G, Rana A, Pradhan N, Singh M, Manandhar B, Giri K. Vaginal Hysterectomy : Learning Experience from Sapporo, Japan 53rd Annual Congress of The Japan Society of Obstetrics and Gynecology. ACOG-JSOG, Sapporo, Japan. May 12-15, 2001, Ref. code 20010512C, ISBN: 88,323-1514-4.

8. Rana A, Gurung G, Pradhan N, Manandhar B. and Giri K. Prolapse \& Problem. Journal of the Society of Surgeons of Nepal, 2001; 4:32-37.

9. Jha R, Pant AD, Jha A, Adhikari RC, Sayami G. Histopathological analysis of hysterectomy specimen. JNMA J Nepal Med Assoc 2006 JulSep; 45(163): 283-90.

10. Kayastha S, Tuladhar H. Vaginal hysterectomy vs abdominal hysterectomy. Nepal Med Coll J. 2006 Dec; 8(4):259-62.

11. Saha R, Sharma M, Padhye S, Karki U, Pandey S, Thapa J. Hysterectomy: an analysis of perioperative and post operative complication. Kathmandu University Medical Journal 2003; 1(2):124-127

12. Rana A, Gurung G, Bista KD, Amatya A, Joshi AB, Sayami J, Shrestha ML, Mishra P. Concomitant rectal and uterovaginal prolapse in the community. JIOM 2006; 28(1); 80-82.

13. Pokharel H, Banerjee B, Koirala R. Prolapsed uterus with huge rectocele and omentocele following cervical amputation: A rare and unusual case presentation. Kathmandu University Medical Journal (2006), Vol. 4, No. 1, Issue 13, 8993

14. Gurung G, Rana A, Magar DB. Uterovaginal prolapse due to portio vaginal fibroma. J Obstet Gynaecol Res. 2003 Jun; 29(3):157-9. 